\title{
ASPECTOS DA AUTONOMIA REFORÇADA (INDEPENDÊNCIA) DAS AGÊNCIAS REGULADORAS
}

\author{
ASPECTS OF ENHANCED AUTONOMY (INDEPENDENCE) \\ OF REGULATORY AGENCIES
}

Artur Carnauba Guerra Sangreman Lima ${ }^{1}$

Recebido em: 24/05/2017

Aprovado em: 22/07/2017

\section{RESUMO}

Inaugurado na década de 1990, o formato da regulação estatal brasileira representa uma mudança de paradigma da atuação estatal, que se caracteriza por uma intervenção indireta do Estado. Trilhou-se o caminho da descentralização administrativa, que ensejou a criação de diversas entidades autárquicas. Ocorre que as agências reguladoras, embora inseridas no conceito de autarquias, são dotadas de uma autonomia reforçada (também denominada de independência). Nesse contexto, afigura-se importante uma análise acerca da independência conferida às agências reguladoras, que se subdivide em quatro diferentes aspectos: independência política dos dirigentes; independência técnico-decisional; independência gerencial, orçamentária e financeira; e inde- 
pendência normativa. Busca-se, assim, mediante uma análise atenta de cada uma das vertentes dessa autonomia reforçada, compreender melhor o funcionamento da atividade regulatória no Brasil, sem olvidar a necessária referência às normas legais e aos posicionamentos jurisprudenciais pátrios.

\title{
PALAVRAS-CHAVE
}

Agência Reguladora. Autonomia Reforçada. Independência. Poder Normativo.

\begin{abstract}
Introduced in the 1990s, the Brazilian regulatory framework represents a paradigm shift in government action, resulting in indirect government intervention. Administrative decentralization was embraced, which then entailed the creation of several autonomous entities. The point is that, although deemed autonomous, these regulatory agencies have in reality an enhanced autonomy (also referred to as independence). In this context, it is relevant to analyze the four different aspects of the independence granted to the regulatory agencies: members are politically unaffiliated; technical and decisional autonomy; budgetary, managerial, and financial independence; and normative independence. Not without referring to the legal rules and to the national case law, it is necessary to carry out a careful analysis of each one of the aspects of this enhanced autonomy in order to better understand how government regulatory activity works in Brazil.
\end{abstract}

\section{KEYWORDS}

Regulatory Agency. Enhanced Autonomy. Independence. Normative Power. 


\section{INTRODUÇÃO}

A consolidação da atividade regulatória do Estado no Brasil, que se insere num contexto de redução da participação direta do Estado no domínio econômico, trilhou o caminho da descentralização, por intermédio da criação de entidades autárquicas, denominadas de agências reguladoras.

Com efeito, as características dessas novas autarquias não correspondiam inteiramente às das autarquias até então existentes. As entidades autárquicas, naturalmente, possuem certa autonomia em relação ao ente político ao qual se encontram vinculadas. Por sua vez, as agências reguladoras foram dotadas de uma autonomia reforçada, ao ponto a doutrina comumente referir-se à existência de uma independência das agências.

É possível apontar quatro diferentes vertentes da independência das agências reguladoras: a) independência política dos dirigentes; b) independência técnico-decisional; c) independência gerencial, orçamentária e financeira; e d) independência normativa. Nessa linha, passa-se a analisar a seguir cada um desses aspectos de forma pormenorizada.

\section{INDEPENDÊNCIA POLÍTICA DOS DIRIGENTES}

A autonomia reforçada das agências reguladoras manifesta-se sob quatro diferentes aspectos, dentre os quais se identifica o viés político. A independência política das agências reguladoras - também denominada por Cuéllar (2001, p. 95) de independência orgânica, uma vez que é assegurada por meio da definição de "regras de composição e de garantias estatutárias" (SILVA, 2015, p. 395) - está intimamente vinculada à isenção da atuação de seus dirigentes, que se desconecta da Administração Direta, circunstância esta relacionada com o processo de escolha daquele que irá ocupar o posto de comando da autarquia regulatória.

Segundo disposto no artigo $4^{\circ}$ da Lei 9.986/2000, as agências serão dirigidas em regime de colegiado por um Conselho Diretor ou Diretoria composto(a) por Conselheiros ou Diretores, sendo um deles o seu Presidente ou o Diretor-Geral ou o Diretor-Presidente. Esse posto de comando somente poderá ser ocupado por brasileiros, de reputação ilibada, formação universitária e elevado conceito no campo de especialidade dos cargos para os quais serão nomea- 
dos, devendo ser escolhidos pelo Presidente da República e por ele nomeados, após aprovação pelo Senado Federal, nos termos da alínea f do inciso III do art. 52 da Constituição Federal de $1988^{2}$.

Cumpre ressaltar que ao conferir a direção e administração das agências reguladoras a órgãos colegiados, como conselhos diretores, busca-se promover uma atuação imparcial, formada pela conjugação de um apanhado de posicionamentos e ideias, sem que a opinião de uma única pessoa prevaleça. Note-se que a posição do órgão regulador será adotada sem uma predisposição aos anseios dos atores regulados nem do governo - este último aspecto é denominado por Calvão da Silva (2015, p. 389) de desgovernamentalização.

Não se pode olvidar que a independência não se manifesta apenas em relação à Administração central, mas também quanto aos operadores privados que compõem os setores regulados, o que se presta a evitar a captura dos agentes reguladores (MODERNE, 2009, p. 113).

Nessa esteira, aduz Calvão da Silva (2015, p. 398-399):

a independência [rectius autonomia] das autoridades reguladoras deve ser garantida não só em relação ao Poder Executivo, mas também quanto aos interesses regulados, porquanto um dos maiores perigos da regulação consiste na possibilidade de o regulador ser "capturado" pelos regulados, de modo a transformar-se numa forma de auto-regulação por meio de entreposto regulador.

A pessoa designada para ocupar o cargo de titular de agência reguladora deverá cumprir três espécies de requisitos distintos. Em primeiro lugar, deve possuir nacionalidade brasileira, seja na qualidade de nato ou naturalizado, o que denota um propósito de preservação do interesse nacional. Em segundo lugar, como mecanismo de valorização da moralidade administrativa, insculpida no caput do artigo 37 da Constituição Federal de 1988, exige-se a reputação ilibada. Finalmente, dois requisitos de caráter técnico, sendo um a exigência de formação universitária e outro a demonstração de destacada experiência no respectivo campo de especialidade, isto é, no setor regulado em que ocupará o cargo.

A escolha dos dirigentes das agências passa pela atuação conjugada dos

${ }^{2}$ Art. 52. Compete privativamente ao Senado Federal: III - aprovar previamente, por voto secreto, após argüição pública, a escolha de: f) titulares de outros cargos que a lei determinar; 
Poderes Executivo e Legislativo, sendo a indicação da autoridade de competência do primeiro, entre brasileiros que preencham os citados requisitos legais, e de competência do segundo a aprovação deste nome, de maneira que a posse e o mandato apenas se iniciam após o segundo ato.

Indiscutivelmente, na prática, é difícil desvencilhar completamente a relação política existente entre os dirigentes e o Chefe do Executivo que o indica. Contudo, os instrumentos adotados - tais como chancela pelo Legislativo acompanhada de sabatina e a estabilidade temporária no cargo (a seguir abordada) - buscam aumentar o grau de isenção e neutralidade.

\subsection{Estabilidade Temporária no Brasil e no Direito Comparado}

Importante aspecto da autonomia política das agências reguladoras é a estabilidade temporária dos seus dirigentes. Conforme disposto nos artigos $6^{\circ} \mathrm{e}$ $9^{\circ}$ da Lei 9.986/2000, os conselheiros e dirigentes das autarquias regulatórias terão mandato com prazo fixo em lei e somente o perderão em caso de renúncia, de condenação judicial transitada em julgado ou de processo administrativo disciplinar. Trata-se da vedação à exoneração ad nutum.

A proibição à exoneração imotivada dos dirigentes das agências, ou seja, seguindo unicamente critérios de conveniência e oportunidade, configura-se como garantia de independência política, na medida em que lhes confere estabilidade temporária no cargo ocupado (com mandato a termo). Esta garantia reforça a autonomia das entidades, porquanto permite a condução de suas atividades de acordo com critérios de ordem técnica, imunizando-as de pressões de cunho eminentemente político.

No direito comparado, a experiência norte-americana revela que a questão já foi objeto de intensa discussão. No caso Myers v. United States, julgado em 1926, a Suprema Corte, por maioria, entendeu que o Presidente possuía a faculdade de exonerar qualquer diretor/dirigente por ele indicado, independentemente da manifestação do Congresso, em face de sua competência para zelar pela fiel execução das leis e porque o poder de exonerar a pessoa designada para o cargo seria decorrência do poder de designar.

Posteriormente, no caso Humphrey's Executor v. United States, julgado em 1935, evoluiu-se o entendimento para considerar constitucional a vedação à exoneração imotivada dos dirigentes das agências reguladoras, ou seja, aco- 
lheu-se a possibilidade de vedação à exoneração ad nutum. Em semelhante sentido, no caso Wiener v. United States, julgado em 1958, a Corte considerou que a natureza quase jurisdicional e quase legislativa das agências reguladoras impunha a restrição à exoneração sem justa causa, mesmo que a lei silenciasse a esse respeito.

Por fim, em 1988, no caso Morrison v. Olson, a Suprema Corte reafirmou a constitucionalidade da restrição ao poder de exoneração ad nutum do Chefe do Executivo, que estaria condicionado à apresentação de justa causa, destacando que "o poder de exoneração, apesar de condicionado a uma good cause, continuava [...] nas mãos do Executivo" (ARAGÃO, 2013, p. 235).

As questões mencionadas, em especial a vedação à exoneração ad nutum dos dirigentes, já foram objeto de análise pelo Supremo Tribunal Federal na Ação Direta de Inconstitucionalidade $n^{\circ} 1.949 /$ RS. Discutia-se a constitucionalidade de dispositivo da Lei instituidora da Agência Estadual de Regulação dos Serviços Públicos Delegados do Rio Grande do Sul, a qual estabeleceu a estabilidade provisória.

A fim de subsidiar a declaração de inconstitucionalidade, arguiu-se que: a) tal sistemática violaria o inciso II do artigo 84 da Constituição Federal de 1988, que se caracteriza como norma de observância obrigatória para os demais Entes da Federação, segundo o qual compete privativamente à Chefia do Poder Executivo o exercício da direção superior da Administração Pública; b) estaria sendo criada uma nova espécie de cargo público, não prevista e não comportada pela ordem constitucional vigente, especialmente porque inexistiria qualquer previsão no sentido da possibilidade de se criar cargo em comissão com estabilidade provisória; e c) essa previsão violaria o princípio democrático, uma vez que os mandatos dos dirigentes ultrapassam os limites do mandato do agente político nomeante, o que iria de encontro à manifestação da vontade popular nas eleições.

Acrescente-se que, até então, prevalecia o entendimento consignado no verbete sumular $\mathrm{n}^{\circ} 25$ do Supremo Tribunal Federal, aprovado em 13.12.1963, segundo o qual "a nomeação a termo não impede a livre demissão, pelo Presidente da República, de ocupante de cargo dirigente de autarquia". Tal entendimento decorreu do julgamento do Mandado de Segurança no 8.693/DF.

Em abono à tese ventilada na propositura da ADI 1.949/RS, Grau sustenta ser inconstitucional qualquer disposição que limite a possibilidade de 
o Chefe do Executivo nomear e exonerar as pessoas designadas para ocupar cargo de dirigente de agência reguladora, já que violaria o regime de governo presidencialista e, especificamente, o artigo 84, II, da CRFB/88 (GRAU, 2009, p. 244).

Por sua vez, o julgamento da mencionada Ação Direta encontrou esteio nas argumentações formuladas pelo Ministro Victor Nunes Leal no julgamento do mesmo Mandado de Segurança, cujo voto restou vencido. Aragão (2013, p. 369) cita trecho desse voto, em que é sintetizada a ideia de independência e autonomia:

\footnotetext{
A investidura de servidor público por prazo certo, eis uma providência que se integra, com toda naturalidade, no regime de autonomia administrativa atribuído, por lei, a certos órgãos. Visa a investidura de prazo certo a garantir a continuidade de orientação e a independência de ação de tais entidades autônomas, de modo que os titulares, assim protegidos contra as injunções do momento, possam dar plena execução à política adotada pelo Poder legislativo, ao instituir o órgão autônomo, e ao definir-lhe as atribuições.
}

O voto condutor da constitucionalidade da estabilidade provisória dos dirigentes das agências reguladoras (ADI 1.949), prevista na lei gaúcha, por unanimidade, consignou a seguinte conclusão: a) viola o princípio da separação de poderes a transferência para o Poder Legislativo da totalidade da competência para destituir dirigente de agência reguladora, de maneira a excluir a participação do Chefe do Executivo; b) em que pese a necessidade de participação do Executivo no referido processo de destituição, a exoneração não pode ficar ao critério discricionário desse Poder, uma vez que isso subverteria a própria natureza autônoma da autarquia especial, o que afasta a possibilidade de exoneração ad nutum; c) a destituição de dirigente de agência reguladora exige a fixação de parâmetros legais precisos; d) ausente a definição desses parâmetros em lei, o mandato fixo somente poderá ser perdido em razão de renúncia, condenação judicial transitada em julgado ou de processo administrativo disciplinar, observando-se em qualquer caso a necessidade de motivação, de processo formal e de inexistência de espaço para discricionariedade do Chefe do Executivo.

A um só tempo, o Supremo Tribunal Federal consolidou a constitucionalidade da sistemática de nomeação dos dirigentes das agências reguladoras, 
mediante indicação do Executivo e aprovação do Legislativo, e da estabilidade provisória dos dirigentes, reconhecendo ser plenamente possível a limitação à exoneração ad nutum (lastreada em critérios meramente discricionários).

Destaque-se que o julgado define como sendo da essência das agências reguladoras a independência política, corporificada em mandato fixo e vedação à exoneração imotivada. Conforme destaca Binenbojm (2006, p. 254), trata-se de uma decisão que, "tendo declarado a constitucionalidade da atribuição, por lei, da estabilidade provisória, representa um leading case na jurisprudência do Supremo Tribunal Federal e, reflexamente, na própria organização político-administrativa do país".

A imunização conferida aos dirigentes das agências reguladoras não se presta unicamente a impedir ingerências por parte do Poder Executivo, mas também a fortalecê-la ante os atores privados. Nesse desiderato, previu-se no artigo $8^{\circ}$ da Lei 9.986/2000 a figura da quarentena, consubstanciada na restrição à liberdade do dirigente após o término do mandato, impedindo-o de prestar qualquer espécie de serviço no setor público ou a empresa pertencente àquele setor regulado.

Destaque-se, ademais, que a citada legislação estabeleceu que a quarentena teria duração de quatro meses, a contar da exoneração do término do mandato do dirigente. Com efeito, diversas leis específicas instituidoras de agências reguladoras definiram prazo de 12 meses (Lei 9.247/1997, que criou a ANEEL; Lei 9.782/1999, que criou a ANVISA; e Lei 10.233/2001, que criou a ANTT e a ANTAQ) ou de um ano (Lei 9.472/1997, que criou a ANATEL), casos em que a legislação específica tem aplicação.

\section{INDEPENDÊNCIA TÉCNICO-DECISIONAL}

A autonomia reforçada das agências reguladoras relaciona-se fortemente com sua independência técnico-decisional, que pode ser sintetizada no caráter final de suas decisões no âmbito administrativo, sempre que proferidas pela autoridade máxima da autarquia, não obstante o respeito à inafastabilidade do controle jurisdicional. Trata-se de independência na perspectiva funcional (SILVA, 2015, p. 395), não submetida a poder hierárquico, o que afasta o cabimento de recurso hierárquico impróprio dirigido à Chefia do Poder Executivo com a finalidade de modificar a decisão proferida por ente 
da Administração Indireta.

A questão, entretanto, não é pacífica na doutrina. No âmbito da descentralização administrativa, o Poder Central cria uma pessoa jurídica para desempenhar determinada atividade, dotando-a de capacidade administrativa e financeira próprias, entretanto, sobre ela exerce a denominada supervisão ministerial, que se dá, na forma do artigo 20 do Decreto-Lei 200/1967, através da orientação, coordenação e controle das atividades dos órgãos subordinados ou vinculados ao Ministério, nos termos desta lei, pelo Ministro de Estado da respectiva área de competência ou pela Presidência da República, quando a vinculação for direta.

Os objetivos da supervisão ministerial estão definidos no artigo 26 do mesmo diploma normativo, a saber: a realização dos objetivos fixados nos atos de constituição da entidade, a harmonia com a política e a programação do governo no setor de atuação da entidade, a eficiência administrativa e a autonomia administrativa, operacional e financeira da entidade.

Neste ponto, percebe-se um duplo aspecto decorrente da capacidade de autoadministração dos entes descentralizados: a) direito de exercer com independência, inclusive em relação ao ente político, as atribuições legalmente outorgadas; b) dever de prestar o serviço nos moldes definidos em lei, o que atrai a competência fiscalizatória do outorgante (DI PIETRO, 2014, p. 558), ressaltando-se apenas que a extensão do controle exercido pelos Ministérios sobre as autarquias não pode ofender a capacidade de autoadministração definida em lei.

Os entes descentralizados são dotados de independência perante o Poder Central para desempenhar determinadas atividades, na forma definida pela legislação de referência. Do mesmo modo, a tutela administrativa, exercida por intermédio da supervisão ministerial, requer previsão legal expressa para poder ser efetivada, não nascendo por presunção nem por analogia.

Importante destacar que a tutela não se confunde com a hierarquia. A primeira, na qual se insere a supervisão ministerial, é um controle realizado pelo Poder Central sobre o ente descentralizado e se reveste de caráter finalístico, isto é, presta-se à verificação da conformidade de sua atuação com seus fins institucionais e com a legalidade, na forma definida em lei. A seu turno, a segunda é realizada nos casos de desconcentração e denota a relação de subordinação no seio da própria Administração Pública. No primeiro caso, há duas 
pessoas jurídicas distintas e o controle (inclusive seus limites) demanda a expressa previsão legal, enquanto no segundo caso a relação se dá no âmbito da mesma pessoa jurídica e independe de previsão legal expressa.

Regra geral, o recurso não constitui manifestação da tutela administrativa, haja vista que seu cabimento se relaciona com a ideia de subordinação hierárquica. A interposição de recursos administrativos contra decisões exaradas pela Administração Pública, direta ou indireta, deve ocorrer no âmbito do próprio órgão ou entidade (mesma pessoa jurídica), motivo pelo qual são denominados de recursos hierárquicos.

Com efeito, quando a lei estabelece o cabimento de recurso para autoridade pertencente a pessoa jurídica diversa daquela que proferiu a decisão, configura-se a hipótese de recurso hierárquico impróprio. Assim, não cabe, ordinariamente, a interposição de recurso perante a Administração Direta contra decisão proferida no âmbito da Administração Indireta. Apenas por exceção se admite o denominado recurso hierárquico impróprio e desde que exista expressa previsão legal.

Nesse sentido, Mello (2013, p. 167) observa que "o Ministro supervisor não é autoridade de alçada para reconhecer de recurso" interposto contra ato expedido por pessoa jurídica diversa, o que inclui a Administração Indireta, de modo que o cabimento de recurso hierárquico impróprio somente se afigura possível quando previsto expressamente em lei.

No caso das autarquias regulatórias, conforme menciona Aragão (2013, p. 372), inexiste lei que preveja a existência de recurso administrativo hierárquico impróprio, "o que por si só bastaria para eliminar tal possibilidade em razão da vetusta doutrina do pas de tutelle sans texte, pas de tutelle au-delà du texte".

Contudo, em caso envolvendo decisão exarada pelo Conselho Administrativo de Defesa Econômica (CADE), o recurso hierárquico impróprio já foi admitido pelo então Ministro da Justiça, Nelson Jobim, ao argumento de que questões relativas a políticas públicas relevantes não poderiam ser retiradas da influência da Administração Central e que o inciso LV do artigo $5^{\circ}$ da Constituição de 1988 garante o contraditório e a ampla defesa com os meios e recursos a eles inerentes.

Este entendimento é perfilhado por Sérgio Guerra (2011, p. 374), acrescentando que as agências reguladoras não refogem ao controle exercido pelos $\mathrm{Mi}$ nistérios e, em última análise, pela Chefia do Executivo, e que a provocação de 
instâncias superiores seria também um direito dos administrados. Com efeito, ele próprio reconhece, em seguida, que a admissão do recurso hierárquico impróprio nesses casos poderia gerar "uma crise no arcabouço institucional estruturado pelo ordenamento jurídico para a eficácia das atividades regulatórias descentralizadas" (GUERRA, 2011, p. 378) e pontua que o poder-dever de a Administração Central manifestar-se na via recursal apenas nasceria quando a agência reguladora invadisse a seara de competência ministerial, ou seja, quando a entidade extrapolasse sua função reguladora.

Tais argumentos, contudo, carecem de sustentação e não justificam a imposição deste forte mecanismo de tutela administrativa sem a necessária previsão legal (ARAGÃO, 2013, P. 374). Há de se ter em mente que as leis instituidoras das agências não só definem seus objetivos, como também os instrumentos indispensáveis à coordenação das políticas públicas do respectivo setor, de forma que a atuação da entidade deverá voltar-se à consecução dos fins estabelecidos, com a preservação de sua autonomia política.

De outro lado, é importante destacar que as leis criadoras das agências dispõem acerca de recursos administrativos contra as decisões proferidas no seio das entidades, o que realiza o mandamento constitucional inserto no inciso LV do artigo $5^{\circ}$ da CRFB/88, não sendo o recurso hierárquico impróprio instrumento indispensável ao respeito do contraditório e da ampla defesa. Ademais, a admissão desta modalidade recursal suprimiria a independência política dos dirigentes, na medida em que a Administração Central poderia impor suas concepções e vontades a qualquer tempo, fazendo prevalecer interesses políticos em detrimento de questões técnicas.

Nessa linha, considerando a natureza autárquica das agências reguladoras e a ausência de previsão legal acerca do cabimento de recurso hierárquico impróprio contra as decisões de seus dirigentes, assim como a inexistência de vínculo de subordinação hierárquica entre a Administração Indireta e o Poder Central, acredita-se ser forçoso o reconhecimento da inadmissibilidade desta via recursal.

\section{INDEPENDÊNCIA GERENCIAL, ORÇAMENTÁRIA E FINANCEIRA}

No âmbito da autonomia administrativa, já se mencionou a estabilidade provisória dos dirigentes das agências, com mandato fixo e imune à exonera- 
ção ad nutum, como forma de proteção da atividade regulatória, garantias que compõem a independência política dos dirigentes e, simultaneamente, fortalecem a atuação da própria entidade.

Com efeito, a independência gerencial engloba também a escolha dos objetivos a serem perseguidos pelas agências no exercício da atividade regulatória, sempre com o necessário respeito à respectiva lei de regência, e dos instrumentos que serão empregados para atingir tais objetivos com a maior eficiência possível. Importante acrescentar que a efetiva autonomia das agências reguladoras passa necessariamente por sua independência financeira, circunstância essencial à consecução a contento de seus objetivos institucionais com isenção e imparcialidade, leia-se, livre de ingerências políticas e influências externas.

A independência financeira reúne a existência de orçamento próprio, com repasses de recursos pelo ente político ao qual esteja vinculado, de patrimônio próprio, transferido no ato de sua criação, e a previsão de outras fontes de receitas próprias, oriundas de taxas de fiscalização referentes aos serviços públicos ou atividades econômicas objeto da regulação, de imposição de multas, de rendimentos de operações financeiras, de recursos de convênios, acordos ou contratos, de doações e de montantes apurados pela venda ou aluguel de móveis ou imóveis pertencentes às autarquias (CUÉLLAR, 2001, p. 94).

Ressalta-se que este aspecto da independência das agências não significa a desnecessidade de respeito ao regime jurídico de direito público, que impõe a obrigatoriedade de licitação como requisito para a celebração de contratos, a realização de concurso público para a contratação de pessoal, às regras de cunho financeiro e orçamentário na realização de despesas, dentre outras.

Esse aspecto da autonomia reforçada das agências, no entanto, pode representar o principal meio de limitação de sua liberdade de atuação. Uma vez que seus orçamentos estão vinculados ao Executivo, a restrição no repasse de recursos pode representar verdadeiro empecilho à sua independência.

\section{INDEPENDÊNCIA NORMATIVA}

A capacidade normativa atribuída às agências reguladoras é, sem dúvida, o tema que suscita maiores discussões e questionamentos por parte da doutrina e da jurisprudência. Não por outro motivo, Gordillo (2013, p. VII-21) aponta os regulamentos como a mais problemática das fontes do Direito Administra- 
tivo. Porém, é também sua mais importante característica, a ponto de Couto e Silva (2015, p. 287) afirmar que "regulação é, na verdade, exercício de poder normativo".

As agências reguladoras foram criadas para promover a retirada do Estado da intervenção direta no domínio econômico, num movimento de migração para a intervenção indireta. Por sua vez, no âmbito da produção normativa, vislumbrou-se que o Poder Legislativo não detinha o conhecimento técnico necessário para deliberar acerca de determinadas matérias, demasiadamente complexas e específicas.

Nessa esteira, tendo em vista a necessidade de o Poder Público continuar a figurar como um ator importante nas questões envolvendo o domínio econômico e a prestação de serviços públicos, definindo parâmetros de conduta para seus respectivos agentes, concebeu-se a atribuição de poder normativo para entidades de caráter técnico como uma forma de contornar essa ausência de conhecimento especializado do legislador e, ao mesmo tempo, de tornar mais imparcial a atuação da Administração Pública, sem olvidar que as leis de outorga da competência normativa contêm as diretrizes e os objetivos a serem perseguidos

A capacidade normativa das agências reguladoras é característica inerente à natureza da atividade por elas desenvolvida, ou seja, a aptidão das agências para editar normas no âmbito do setor regulado é atributo próprio de sua atuação, sem a qual a atividade regulatória perde a sua essência. A regulação "pressupõe a edição de regras que disciplinem o comportamento das pessoas em sociedade, mediante a limitação de direitos subjetivos de que são titulares em benefício do convívio harmonioso de todos" (COUTO E SILVA, 2015, p. 287).

Glauco Martins Guerra (2004, p. 297) conceitua a regulação sob a perspectiva do poder normativo das agências reguladoras:

É possível afirmar que a regulação é uma atividade jurídica de franca produção normativa tipicamente desenvolvida para um modelo econômico capitalista, no qual o Estado, como agente legitimado para o exercício da função legislativa e da força coercitiva, intervém no mercado produtivo mediante instrumentos de autoridade, objetivando delinear a atividade empresarial em consonância com os interesses públicos, sociais e econômicos.

No que toca especificamente aos serviços públicos, o mesmo conceito acima pode ser aplicado, com o adendo que o Estado deixa de realizar diretamente as 
atividades econômico-produtivas (empresariais), ainda que consideradas de natureza essencial, promovendo-as ao particular, que renderá sua atuação às regras e normas ditadas pelo agente regulador, seja no que toca às questões técnico-operacionais, à defesa dos interesses do consumidor e à proteção da livre concorrência.

Porém, é possível verificar, no campo doutrinário, posições diametralmente opostas quanto à admissibilidade do poder normativo. A de cunho mais restritivo, na qual se inserem Clève (2014, p. 247 et. seq.) e Couto e Silva (2015, p. 289-290), identifica o regulamento como mera manifestação do poder regulamentar (para a fiel execução de leis), previsto no artigo 84, IV, da Constituição Federal de 1988, de maneira que não se afiguraria possível a inovação no ordenamento jurídico através de ato normativo dessa natureza, bem como seria inaplicável à realidade brasileira a tese da delegação legislativa.

Por outro lado, a tese favorável à outorga de poder normativo às agências reguladoras defende que os regulamentos encontrariam espeque na tese da deslegalização e seriam dotados de respaldo constitucional, em perfeita sintonia com a atual visão acerca do princípio da legalidade. Essa visão simpática à capacidade normativa das agências foi bem sintetizada por Binenbojm (2006, p. 260), que faz referência à possibilidade de inovação no ordenamento jurídico, editando normas de caráter primário:

Dado o amplo grau de generalidade e abstração característico das leis de criação das agências (as chamadas broad delegations, como referidas na literatura publicista norte-americana), estas últimas são investidas de grande autonomia normativa, do que decorre, por inevitável imposição prática, a elaboração de normas jurídicas em caráter primário. A produção de normas com aptidão para inovar no ordenamento jurídico, criando direitos e obrigações, constituiria, assim, segundo parcela significativa da doutrina nacional e alienígena, autêntica nota característica das agências reguladoras.

Na busca por afastar as críticas mencionadas, é importante destacar que tanto o poder regulamentar do Executivo quanto o poder normativo das agências reguladoras possuem o devido amparo no plano constitucional - a Constituição Federal de 1988 dedicou-se a definir ambas as competências normativas. Contudo, não é possível enquadrá-las sob o mesmo manto, uma vez que elas não possuem a mesma natureza jurídica.

Em primeiro lugar, cumpre registrar a ausência de violação ao princípio 
da legalidade, atualmente compreendida como juridicidade (sob o influxo da constitucionalização do direito administrativo). Paulo Otero (2003, p. 158) anota que o "desenvolvimento do sentido e do valor da Constituição [...] veio impregnar a legalidade administrativa de uma dimensão constitucional que antes lhe era alheia".

Para o autor português, a visão tradicional do princípio da legalidade administrativa encontra-se "desesperadamente ultrapassada", de maneira que já não pode ser visto sob uma perspectiva fechada e rígida:

em vez disso, assiste-se a uma progressiva indeterminação e abertura densificadora da normatividade a favor da Administração Pública que, por esta via, adquire um crescente activismo na revelação e construção das soluções concretas e regulamentares, conferindo-se uma inerente maleabilidade à legalidade administrativa, que vive tempos de erosão do seu habitual e repetido papel puramente vinculativo da actuação administrativa. (OTERO, 2003, p. 894).

As agências reguladoras, ao editarem os regulamentos, precisam respeitar o bloco de legalidade, especialmente os preceitos e valores constantes da Constituição Federal de 1988. Todavia, não se afasta a aptidão para inovar no ordenamento jurídico, ainda que se refira à edição de regramentos com caráter técnico e compatíveis com diretrizes traçadas pelo legislador. Portanto, diz-se que a atuação da Administração Pública demanda uma atribuição de competência, não se admitindo mais o vetusto conceito de legalidade administrativa que restringia sua atuação ao que estivesse previamente estipulado em lei.

Neste ponto, é pertinente a distinção entre reserva legal absoluta e relativa. A primeira refere-se à exigência de que determinada matéria seja inteiramente tratada no âmbito do Poder Legislativo, regradas integralmente por lei em sentido formal, sem que remanesça qualquer margem para a atuação discricionária dos agentes públicos (MOREIRA NETO, 2003, p. 57). A segunda diz respeito à desnecessidade de um regramento exaustivo da matéria no plano legal, permitindo que o legislador se restrinja a fixar parâmetros de atuação, os quais demandarão posterior complementação por atos infralegais emanados dos órgãos administrativos, de modo que compete ao Legislativo apenas a definição de parâmetros. A ideia de juridicidade enquadra-se nesse contexto, porquanto não vincula a conduta administrativa à estrita previsão legal, admitindo que a Administração se conduza embasada em habilitação legal, sem afastar a neces- 
sidade de respeito ao Direito.

Cabível também distinção entre reserva de lei formal e material. No primeiro caso, a disciplina de determinada matéria é exclusiva do Poder Legislativo, na forma rigidamente descrita no Texto Constitucional. Deste modo, verifica-se a reserva de lei formal "quando determinada matéria possa ser tratada por ato emanado do Poder Legislativo, mediante adoção do procedimento analítico ditado pela própria Constituição" (MOREIRA NETO, 2003, p. 57). No segundo, fala-se em atos materialmente legislativos, a significar que possuem força de lei, apesar de não emanados do Parlamento. Assim, é possível falar que houve uma atenuação da concepção clássica de legalidade com a outorga de poder normativo para as agências reguladoras.

A configuração oitocentista do princípio da legalidade administrativa vem sendo objeto de reformulação, com reflexo sobre a noção de reserva legal. No direito comparado, Paulo Otero (2003, p. 734) já sustenta que à Administração Pública é facultada, em regra, a atuação com fundamento direto na Constituição, exceto nos casos de reserva de lei expressamente definidos no texto constitucional.

\footnotetext{
Encontra-se aqui exposta, por conseguinte, uma via de rotura do mito da omnipotência da lei em face da Administração Pública e da consequente menoridade ou inferioridade da Constituição perante a lei no âmbito da função administrativa: em vez de a eficácia operativa das normas constitucionais estar sempre dependente da lei na sua vinculatividade para a Administração Pública, tal como se encontra subjacente ao pensamento liberal oitocentista. A lei deixou de ter hoje o monopólio habilitante da actividade administrativa, registrando-se que a aplicação da Constituição à Administração Pública e pela Administração Pública não exige necessariamente a mediação legislativa (OTERO, 2003, p. 735).
}

Otero (2003, p. 743) acrescenta, ainda, que a substituição da lei pela Constituição no papel de centralidade na atribuição de competências aos órgãos da Administração Pública (desmistificação da onipotência da lei ou debilitação da centralidade da lei) afasta a máxima operatividade do princípio da precedência da lei em relação à Administração, inclusive no que concerne à intervenção de normas de diversas naturezas (utilizando o Direito Comunitário e o Direito Internacional como exemplos).

Nesse contexto, a admissibilidade das normas reguladoras promove uma 
ressignificação do princípio da legalidade, seja sob a perspectiva da Administração Pública, porque autorizada a atuar com fundamento em norma habilitadora, seja em relação ao particular, na medida em que aceita a possibilidade de o Executivo editar normas de caráter geral e abstrato com aptidão para inovar, as quais deverão ser observadas por todos os atores da regulação (públicos ou privados).

Elaborado um panorama sobre a atividade normativa regulatória frente ao princípio da legalidade, é indispensável mencionar que o poder normativo das agências reguladoras pode ser explicado de acordo com a teoria da deslegalização, compreendida como espécie de delegação legislativa que promove a modificação do plano normativo em que se dará a normatização de determinadas matérias, passando para a seara do regulamento questões anteriormente reservadas à lei, sem que se configure a negação de sua primazia.

Por consequência, há um alargamento da competência normativa do Executivo promovido pelo próprio Legislativo ao transferir a capacidade de estabelecer regras. As normas reguladoras, registre-se, são dotadas de abstração, generalidade e aptidão para inovar no ordenamento jurídico, ou seja, "os regulamentos possuem caráter normativo" (LIMA, 2015, p. 58).

As autarquias regulatórias não usurpam a função legislativa, já que a competência para editar leis permanece com o Poder Legislativo. O poder normativo das agências não afasta o poder de legislar, conformando-se como um aprofundamento da atuação normativa estatal, tendo em vista a necessidade de normas com caráter técnico, específicas para atender às exigências de determinado setor:

a agência não é usurpadora da função legislativa. Esta continua a caber ao Poder Legislativo, que edita leis, frequentemente com um grau de abstração e generalidade que não mais atende aos novos padrões da sociedade, sendo necessárias normas que tratem das especificidades, que realizem o planejamento dos setores, viabilizem a intervenção do Estado em garantia do cumprimento ou da realização daqueles valores. Daí a atribuição de poder normativo para as agências, o qual não exclui o poder de legislar, mas mero aprofundamento da atuação normativa do Estado. (SOUTO, 2005, p. 247-248)

Observa Moreira Neto (2003, p. 117) que as normas editadas no exercício da atividade regulatória possuem natureza eminentemente técnica (distancia- 
das do viés político), de modo que se apresentam como a via mais adequada para regrar questões de tal natureza. Contudo, nem sempre se fez necessária a distinção entre escolhas político-administrativas e matérias de ordem predominantemente técnica, porquanto o Parlamento, historicamente, albergou integralmente ambas as competências. A necessidade de segmentação surge apenas com a crescente "complexificação da conveniência social", a fim de evitar a obsolescência de regras de ordem técnica no plano legal.

Ressalte-se que a norma regulatória, conforme leciona Souto (2005, p. 28), deve ser editada para disciplinar questões de ordem técnica, sem se imiscuir na seara política. Noutras palavras, a valoração política fica ao encargo da lei que cria a agência reguladora e traça os objetivos a serem alcançados naquele setor, cumprindo à autarquia regulatória estabelecer regras de natureza técnica com o fito de realizar estes fins.

Não se fala, no âmbito das agências reguladoras, em ausência de intermediação legal entre os regulamentos e a Constituição. Verifica-se a utilização das denominadas leis-quadro, que se caracterizam por definir parâmetros de atuação a serem posteriormente integrados por ato normativo diverso de lei, no caso, o regulamento. Assim, considerando a complexidade e a tecnicidade da matéria, as leis limitam-se a definir standards, fins a serem perseguidos, configurando-se como de baixa densidade normativa. Noutras palavras, "a delegação, ainda que possível, não pode ser 'em branco', isto é, desacompanhada de parâmetros ou diretrizes obrigatórias" (MOREIRA NETO, 2003, p. 59).

As competências legislativas foram conferidas ao Poder Legislativo, razão por que é necessário, mesmo na seara da reserva legal relativa, que a norma legal defina contornos mínimos (princípios a serem seguidos e objetivos a serem alcançados) acerca da disciplina de cada matéria, como forma de orientar a edição dos regulamentos e permitir o controle. Não se afigura possível a simples transferência de competência normativa sem a definição de parâmetros mínimos de atuação, o que representaria "verdadeira abdicação da função de legislar sobre o assunto, aí sim, uma subversão da legalidade e do sistema de distribuição de competências previsto na Constituição" (BRUNA, 2003, p. 117).

Sobre a necessidade de lei que respalde a atuação das agências reguladoras no exercício de seu poder normativo, Carvalho Filho (2011, p. 67) aduz: "ainda que dotada de grande amplitude, a regulamentação feita pelas agências [...] terá que adequar-se aos parâmetros da respectiva lei permissiva", haja vista 
que "a delegação legislativa não é ilimitada, mas, ao contrário, subjacente a normas e princípios estabelecidos na lei".

Nesse sentido, Bruna (2003, p. 93) enquadra o poder normativo das agências no conceito de regulamentos autorizados (ou por delegação), por se tratar de competência normativa conferida pelo Legislativo ao Executivo diante de circunstâncias mutáveis e essencialmente técnicas, em que o primeiro se limita a estabelecer princípios gerais e ao segundo incumbe a expedição do respectivo regramento.

Enfim, o poder normativo das agências reguladoras não se confunde com o poder regulamentar da Chefia do Executivo, pois não se limita à fiel execução da lei (LIMA, 2015, p. 59). Enquanto o poder regulamentar encontra fundamento no artigo 84, IV, da Constituição Federal de 1988, os regulamentos são editados com fulcro nos artigos 21, XI, 174 e 177, § $2^{\circ}$, II, também da CRFB/88, bem como nas leis deslegalizadoras. Ademais, ambos possuem características/finalidades distintas: enquanto o poder regulamentar se presta a promover a fiel execução da lei, o poder regulador disciplina a matéria deslegalizada, com abstração e generalidade, sendo instrumento apto a inovar no ordenamento jurídico.

Os regulamentos expedidos no exercício da atividade regulatória caracterizam-se como normas, porém, "no direito público, as normas reguladoras surgem como espécies normativas sui generis, distintas das normas legais tradicionais, empregadas no Direito Administrativo" (MOREIRA NETO, 2003, p. 113). Portanto, as normas reguladoras não se confundem com as normas legais, originárias do Poder Legislativo, tampouco com as regulamentares, provenientes do Poder Executivo. Não obstante editadas no âmbito da Administração Pública, as normas reguladoras possuem natureza jurídica própria.

\section{CONSIDERAÇÕES FINAIS}

Em suas diversas vertentes, a autonomia reforçada (independência) é uma das principais características da atividade regulatória do Estado, um atributo indispensável ao adequado cumprimento das competências legalmente atribuídas às agências reguladoras.

A independência orgânica, que se traduz na independência política dos dirigentes, significa que a atuação das agências não busca realizar os interesses do setor regulado, do ente político ao qual se encontra vinculado ou do 
governo eleito. A atuação das autarquias regulatórias deve ser pautada em critérios de natureza técnica. Nesse contexto, a escolha dos dirigentes ocorre de forma conjugada, fruto da indicação do Poder Executivo e aprovação do Poder Legislativo, e é vedada a exoneração imotivada dos escolhidos (estabilidade temporária).

A independência técnico-decisional exprime o caráter eminentemente técnico da atuação das agências reguladoras e, não obstante a inafastabilidade do controle jurisdicional, assegura a o caráter final de suas decisões na seara administrativa, o que revela o não cabimento de recurso hierárquico impróprio.

A independência gerencial, orçamentária e financeira reflete a faculdade para eleger os objetivos que serão perseguidos no exercício da regulação, sem esquecer as diretrizes constantes da lei, bem como a necessidade de orçamento próprio, com repasse de recursos pelo ente político e previsão de fontes de receitas próprias.

Em que pese a importância dos aspectos acima citados, a independência normativa merece ser qualificada como o principal atributo da regulação. A essência das agências é a capacidade para editar normas de caráter técnico no âmbito do setor que se prestam a regular. Tal outorga de competência é feita diretamente pelo Legislativo, que retira determinada matéria do domínio da lei, passando-a ao domínio do regulamento, o que se denomina de deslegalização ou delegificação.

Na regulação, o poder normativo é conferido pelo próprio núcleo político do poder estatal, na medida em que decorre da atuação conjunta dos Poderes Executivo (ao trilhar o caminho da descentralização administrativa) e Legislativo (ao editar as normas instituidoras das agências com a competência para expedir os regulamentos). Conforma-se, assim, como uma releitura do princípio da separação de poderes (LEHFELD, 2008, p. 263) e da legalidade, por intermédio da qual se compreende possível que entidades integrantes do Poder Executivo estabeleçam regras de conduta no respectivo setor regulado, as quais deverão ser obrigatoriamente cumpridas pelas diversas pessoas que o compõem.

Diante deste cenário, com a pretensão de sintetizar a ideia de independência normativa das agências reguladoras - uma das manifestações de sua autonomia reforçada -, é possível compreendê-la como a outorga de poder normativo pelo Legislativo a entidade da Administração Indireta para editar normas de natureza técnica no âmbito do respectivo setor regulado, com o es- 
copo de realizar os objetivos traçados na lei. Observe-se que os regulamentos são fruto de habilitação legal, dotados de caráter normativo e de aptidão para inovar no ordenamento jurídico, possuindo natureza jurídica de norma sui generis, inconfundíveis com normas legais.

\section{REFERÊNCIAS}

ARAGÃO, Alexandre Santos de. Agências Reguladoras e a Evolução do Direito Administrativo Econômico. 3. ed. Rio de Janeiro: Forense, 2013.

BINENBOJM, Gustavo. Uma Teoria de Direito Administrativo: direitos fundamentais, democracia e constitucionalização. Rio de Janeiro: Renovar, 2006.

BRASIL. Supremo Tribunal Federal. Ação Direta de Inconstitucionalidade no 1.949. Relator: Ministro Dias Toffoli. Tribunal Pleno. Julgado em 17 de setembro 2014. Publicação em 14 de novembro 2014. Disponível em: <http://redir.stf.jus.br/paginadorpub/paginador.jsp?docTP=TP\&docID=7237463>. Acesso em: 30/10/2015

BRUNA, Sérgio Varella. Agências Reguladoras: poder normativo, consulta pública, revisão judicial. São Paulo: Revista dos Tribunais, 2003.

CARVALHO FILHO, José dos Santos. Agências Reguladoras e Poder Normativo. In: ARAGÃO, Alexandre Santos de (Coord.). O Poder Normativo das Agências Reguladoras. $2^{\mathrm{a}}$ ed. Rio de Janeiro: Forense, 2011.

CLÈVE, Clèmerson Merlin. Poder Normativo da Administração Pública. In: MELLO, Celso Antônio Bandeira de; FERRAZ, Sérgio; ROCHA, Silvio Luís Ferreira da; SAAD, Amauri Feres (coord.). Direito Administrativo e Liberdade - estudos em homenagem a Lúcia Valle Figueiredo. São Paulo: Malheiros, 2014.

COUTO E SILVA, Almiro do. Conceitos Fundamentais do Direito no Estado Constitucional. São Paulo: Malheiros, 2015. 
CUÉLLAR, Leila. As Agências Reguladoras e Seu Poder Normativo. São Paulo: Dialética, 2001.

DI PIETRO, Maria Sylvia Zanella. Direito Administrativo. $27^{\mathrm{a}}$ ed. São Paulo: Atlas, 2014.

GORDILLO, Agustín. Tratado de derecho administrativo y obras selectas: parte general (tomo 1). 1. ed. Buenos Aires: Fundación de Derecho Administrativo, 2013.

GRAU, Eros Roberto. La regulación em Brasil. In: MARCOU, Gérard; MODERNE, Franck (org.). Derecho de la regulación, los servicios públicos y la integración regional. Tomo I. Bogotá: Editorial Universidad de Rosario, 2009, p. 244.

GUERRA, Glauco Martins. Agências Reguladoras no Brasil: Princípio da Legalidade e Regulação. In: DI PIETRO, Maria Sylvia Zanella (org.). Direito Regulatório: temas polêmicos. Belo Horizonte: Fórum, 2004.

GUERRA, Sérgio. Agências Reguladoras e a Supervisão Ministerial. In: ARAGÃO, Alexandre Santos de (Coord.). O Poder Normativo das Agências Reguladoras. 2. ed. Rio de Janeiro: Forense, 2011.

LEHFELD, Lucas de Souza. Controles das Agências Reguladoras. São Paulo, Atlas, 2008.

LIMA, Artur Carnauba Guerra Sangreman. Os Novos Contornos do Princípio da Legalidade e o Poder Normativo das Agências Reguladoras. In: CARVALHO, Fábio Lins de Lessa (coord.). Direito Administrativo Inovador. Curitiba: Juruá, 2015.

MELLO, Celso Antônio Bandeira de. Curso de Direito Administrativo. 30. ed. São Paulo: Malheiros, 2013.

MODERNE, Franck. Los usos de la noción de regulación em el derecho positivo y en la doctrina jurídica de los Estados de la Unión Europea. In: MARCOU, Gérard; MODERNE, Franck (org.). Derecho de la regulación, los servicios públicos y la integración regional. Tomo I. Bogotá: Editorial Universidad de Rosario, 2009.

MOREIRA NETO, Diogo de Figueiredo. Direito regulatório. Rio de Janeiro: Renovar, 2003. 
OTERO, Paulo. Legalidade e Administração Pública - O Sentido da Vinculação Administrativa à Juridicidade. Coimbra: Almedina, 2003.

SILVA, João Nuno Calvão da. Poderes e Instrumentos Regulatórios da Entidades Reguladoras ao Abrigo da Lei-Quadro das Entidades Administrativas Independentes com Funções de Regulação da Atividade Económica dos Sectores Provado, Público e Cooperativo. In: GONÇALVES, Pedro Costa (org.). Estudos de Regulação Pública - II. Coimbra: Coimbra Editora, 2015.

SOUTO, Marcos Juruena Villela. Direito administrativo regulatório. Rio de Janeiro: Lumen Juris, 2005.

SUPREMA Corte dos EUA. Myers v. United States, 272 U.S. 52 (1925). Disponível em: <https://supreme.justia.com/cases/federal/us/272/52/case.html>. Acesso em: 1/3/2016.

SUPREMA Corte dos EUA. Humphrey's Executor v. United States, 295 U.S. 602 (1935). Disponível em: <https://supreme.justia.com/cases/federal/us/295/602/ case.html>. Acesso em: 1/3/2016

SUPREMA Corte dos EUA. Wiener v. United States, 357 U.S. 349 (1958). Disponível em: <https://supreme.justia.com/cases/federal/us/357/349/case.html>. Acesso em: 1/3/2016.

SUPREMA Corte dos EUA. Morrison v. Olson, 487 U.S. 654 (1988). Disponível em: <https://supreme.justia.com/cases/federal/us/487/654/case.html>. Acesso em: $1 / 3 / 2016$. 